\title{
Factors Affecting Teacher Performance at Junior High Schools in DKI Jakarta, Indonesia
}

\author{
Ahmad Hidayat, Zaman Zaini \\ Institut Ilmu Sosial dan Manajemen STIAMI, Faculty of Public Administration, Let. Jend. Suprapto Road, DKI Jakarta 10530, Indonesia
}

\begin{abstract}
The purpose of this study is to determine the most dominant factors that affect the performance of teachers in the teaching process. The study population is a public high school teacher who located in DKI Jakarta. The number of questionnaires distributed and received by respondents was 215 questionnaires then returned only about 175 questionnaires. Multiple linear regression analyzed data with the help of IBM SPSS program. Teacher performance variable $(Y)$ as the dependent variable, during teacher attitude $\left(X_{I}\right)$ and quality of supervision $\left(\mathrm{X}_{2}\right)$ as the independent variable. Measurement of validity and reliability using Alpha Cronbach. The result showed that there was a significant influence between attitude variable $\left(X_{I}\right)$ on teacher performance $(Y)$ and also there was a considerable influence between quality supervision variable $\left(\mathrm{X}_{2}\right)$ on teacher performance $(Y)$. From the research, it can conclude that attitude variable is dominant factor which tends to influence teacher performance in interaction process of teaching-learning. In this case, the teacher should be able to improve his performance which is the capital for the success of education.
\end{abstract}

Keywords: Teacher Attitudes, Quality of Supervision, Teacher Performance

\section{Introduction}

In essence, the quality of human resources is a subject and object of development that determines through education. Improving the quality of education at all levels is a must when viewed from the framework of preparing the Indonesian human resources so that the graduates can compete and can overcome the problems of life in the future [1]. Characteristic of a condition like this is only human resources that have a quality that can and can face competition. In this regard, one aspect of concern for the future development of education is improving the quality of human resources.

The endeavors to improve the quality of Junior High School or overall education are realized in the management, arrangement in the improvement of the ability of each component in education activities in Junior High School such as institutional system, curriculum development, quality improvement of educational staff and other inputs such as books, props and other facilities for teaching management in schools [2]. Every effort to improve the quality of education is the most systematic effort related to one level of knowledge to the next level of education.

Personnel school personnel such as principals and teachers are a determinant of success in conducting educational activities. The teacher is the spearhead in translating the school mission of implementing learning as the primary activity in school education [3]. To that end, efforts to improve teachers' skills and skills must continuously pursue through education and training. It intended that teachers who perform duties at the secondary education level have the skills and skills that are standard (professional), that is the skills or skills needed for a teacher to carry out the learning task.

Teachers are a very dominant factor and most crucial informal education in general because teachers are often used as role models for students, even a figure of self- identification [4]. Therefore, teachers should have optimal behavior and performance to develop the quality of graduates. It is said that the higher the performance of teachers in carrying out their duties, allegedly the higher the quality of graduates. To carry out their duties well by the profession it has, teachers need to master various things as competence. On the other hand, the teacher must understand and appreciate the students he/she guides, because the students' form at all times will not be the same because the development of science and technology that gives impact and cultural values of Indonesian society significantly affect the picture of the graduates of an expected school. Therefore, the supposed image of teacher behavior is very influential and influenced by the situation so that in performing their duties as teachers, teachers should be able to anticipate the development of circumstances and demands of society in the future.

Teachers as professionals in the field of education about accountability, the task does not mean to be lightweight, but even more severe to provide services to the community, especially students. Therefore, teachers are required to qualify for an adequate ability, so that they can perform their duties well in other ways to show good performance. In the process of teaching and learning the performance of teachers can be seen from the extent to which the quality of teacher work in teaching and teacher competence can implement. Three factors should be considered as an indicator of teacher quality because it influences as a supporter of teachers to create effective learning process, namely: (1) general ability, (2) perception of the profession, (3) attitude as a teacher. Thus, it can assume that positions as teachers in the sense of attitudes toward the teaching profession can affect the performance of teachers [5].

The attitude of the teacher to his profession is something that needs to pursue positively because having a positive attitude towards his job will encourage the emergence of sense to like and like his career. When it grows in a teacher, then by itself will be able to add enthusiasm and excitement in work. Attitude as a tendency to act allows it to directed toward the 


\section{International Journal of Science and Research (IJSR) \\ ISSN (Online): 2319-7064}

Index Copernicus Value (2015): 78.96 Impact Factor (2015): 6.391

formation of behavior [6]. In the context of teachers, the expected behavior is related to action and deeds in performing their professional duties as teachers or educational personnel.

On the other hand, to improve and develop skills that describe teacher performance, each teacher needs to be supported by the implementation of educational administration through an orderly and orderly supervision. Quality education supervision activities carried out in schools can help the smooth process of learning exercises and performance of teachers in carrying out their duties [7]. Meanwhile, to improve performance, the actions of school supervision are something that should do well. Good supervision activities and quality can support the atmosphere of learning activities carried out professionally characterized by the implementation of administrative operations of all aspects of learning activities [8]. It is a form of guidance given to all school staff so that they can improve their ability to develop better teaching and learning situations. The principal who believes that the school's supervisory activities are of high quality will feel that all school activities will better implement, which will improve teachers' performance in the learning process.

School as an organization requires personnel who can realize and achieve the goals of the organization itself. Therefore, teachers as a component of school personnel should always show excellent performance in carrying out the work, so that optimally can achieve the expected results of its duties. As a teacher or teacher at the school.

Thus, it can argue that the improvement of teacher performance can determine the teacher's attitude factor and the quality factor of supervision. Therefore, this study aims to be able to decide on the dominant influence on teacher attitudes and the quality of control on teacher performance.

\section{Theoretical Framework}

\subsection{Performance}

The term performance in this paper intended as a translation of the word performance, which can interpret as the ability to show the seriousness of carrying out the work [9]. Assessment of teacher performance relates to the central issues of evaluation of teaching activities themselves, and teaching behavior used as a basis for assessing production [10]. The concert also means as a measure of work [11]. Therefore, the performance of this teacher can interpret as a condition that shows the ability of a teacher in carrying out his duties at school and describes the existence of an act displayed teacher in or during teaching activities.

Teachers have a good performance if the relevant understand the functions and duties well. Therefore, a teacher has a stock or knowledge of the profession that is so well known about the task that must do, so that teachers can distinguish and understand the priorities of work that must and should not be done [12]. To demonstrate good performance, skills targets and specific abilities for the teacher's position are required, such as mastering the basic competence of teachers. Therefore, from the personal aspect, it is necessary to have a broad responsibility and awareness to create a good performance because it can say that the performance is related to employee awareness of their work [13].

In the learning process, teacher performance closely related to student achievement. The performance of good teachers will result in excellent student learning achievement as well. Furthermore, the superb performance seen from the results obtained. From the assessment of student outcomes, then some teacher performance indicators appear regarding student and parental satisfaction, student learning achievement, social behavior, and teacher attendance [14]. Thus, it is clear that assessing and understanding the performance of teachers cannot be separated from students as students, and the achievement of learning achievement of students describes the performance of teachers as planners and teaching managers or class administrators. Meanwhile, production is also related to the level of knowledge and ability to solve the problem [15].

According to [16] Performance refers to the degree of accomplishment of the tasks that make up an individual is fulfilling the requirements of a job. Opinion defined that the performance or performance refers to the degree of completion of tasks that complement one's work. It reflects how well a person is in carrying out the demands of a job.

In expectancy theory, it proposed that performance is the result of interaction between motivation with the ability (essential ability). The implications of the theory show that people who are highly motivated but have low necessary skills will produce a weak performance. So it is with people who have a high primary ability, but little motivation, then its return becomes level [17]. If so, then in addition to necessary skills, partially motivation can be one element of performance, and motivation can interpret as a business that encourages to perform a task. Therefore, an essential concept of the theory above is that to reveal and measure teacher performance can be done by reviewing the necessary skills of teachers or the implementation of critical competence of teachers.

Based on the description in advance, it can be concluded that the performance of teachers is primarily a manifestation of a kind work that relates to the ability of teachers in carrying out their duties, both as teachers, mentors, and administrators of the class.

\subsection{Attitude}

Attitude is the readiness to act regarding thoughts and emotions [18]. Meanwhile, beliefs as a result of learning obtained through experience or tendency towards a particular object that gives rise to a feeling of support for the purpose [19]. Furthermore, it can say that attitude is an assessment of statements, likes or dislikes objects, people or events [11]. Of the three meanings above shows that approach is the result or manifestation of the learning process, it implies that beliefs can be learned. In addition to that, there is a level of positive and negative feelings or support or non-support that

\section{Volume 6 Issue 11, November 2017}




\section{International Journal of Science and Research (IJSR) \\ ISSN (Online): 2319-7064}

Index Copernicus Value (2015): 78.96 | Impact Factor (2015): 6.391

associated with psychological objects. It means that when a person has a positive atmosphere for a mental purpose, it can say that he or she likes the use or a favorable attitude. While people who are negative toward the psychological object can tell that the person does not want or have an unfavorable opinion.

In other sources mentioned, attitudes as a tendency to react in a certain way to groups of events, objects or individuals [20], therefore belief is the readiness to respond to a particular purpose, not as it is but as it lives. This conception shows the tendency to react to social objects where interaction with situations and other variables that guide and direct the real behavior of the individual. As stated that attitudes will only be meaningful when displayed in the form of a statement of response, both verbal and behavioral functioning. Another limitation explains that a relatively fixed position includes feelings, beliefs, and tendencies toward specific objects [21]. The concept of attitude above divides attitude into three groups or components that interact with each other. These three parts are binding together, in the sense that the individual's understanding of a particular object influenced by feelings, beliefs, and the tendency to act. If there is a change in one component, then the other parts also change as well.

Judging from the structure, the attitude consists of three components that support each other, namely: (1) cognitive element in the form of what is believed by the subject-owner manner; (2) active part is a component of feelings that concern the emotional aspect; and (3) conative component is an aspect of individual behavioral trends in accordance with attitudes possessed by the subject [14].

Measurement of attitude is one crucial aspect to understand human attitudes and behavior. Analysis of approaches in this context is intended to measure the level of individual effectiveness ranging from positive and negative, which is related to psychological objects. There are two well-known measurement methods, namely Likert and Turnstone methods. In this study used Likert model attitude scale that is considered pure, high accuracy because it uses five alternative answers, and secure in processing [22].

The characteristics of the Likert model's attitude scale are: (1) does not require the use of categories by appraisers, even though experts are still needed to select statements and to smooth them. Thus, there is a simplification of the procedure and its construction: (2) the fact that the measured attitude is not limited to the two alternative answers, but the subject is faced with five choices of strongly agree, agree, hesitate, disagree, strongly disagree. Based on the description in advance, it can conclude that essentially attitude is a relatively permanent mental willingness to react to an object, either, positively, neutral or negative concerning cognitive (trust), affective (feeling), and conative (actions).

\subsection{Quality Supervision}

The quality is the goal to be achieved by each or group in carrying out its activities both for its interest and for the benefit of the organization [23]. In the various activities undertaken by quality education institutions are things that should be in priority, as an effort to produce learners who have quality and can meet market needs [24].

The quality of supervision in the effort to realize the quality of a good school is becoming increasingly important in two aspects [25]. First is the element of competition. Competition occurs between the school itself and game in the workplace. Currently, every prospective worker must be equipped with quality education to get a steady job. Therefore, he should be a qualified graduate of an eligible educational institution. Furthermore, schools should be managed by trained teachers and managers, if they are to produce quality learners in both quality and quantity. The second aspect that requires educational institutions to provide quality learners is the emergence of freedom for educational institutions themselves to control the education process in their environment. The various regulations that hinder the government bureaucracy are diminishing. Greater freedom requires greater responsibility [26]

Educational institutions should demonstrate goodwill to provide quality education for learners. Thus, in the context of free competition today every school must compete in improving the quality of education [27]. Otherwise, the graduate will not be able to compete to continue his studies and to gain a place in the world of work. It is in this context that every educational institution should reflect on quality improvement strategies.

The impact of quality education and graduates, with the development of optimal knowledge, skills, and personality, directly contributes to improving the quality of people's lives. Thus, the efforts of educational institutions at the elementary level should also generate added value for the community [28].

Thus, regarding people who supervised, supervision is a learning process that produces new knowledge, attitudes, and job skills. In other words, institutional control aims at generating changes in the behavior of school staff, especially teachers, so that they can perform their duties in school as professional educators [29].

The scope of supervision includes various aspects of the learning activities, as the applicable curriculum implementation. Thus, the supervision program provides research and guidance on curriculum, workforce, administration, education facilities and relationships with the community.

\section{Method}

This study involved respondents as a sample. Type of survey research using questionnaires to obtain primary data distributed by random sample technique to the respondents in the study area.

\section{Volume 6 Issue 11, November 2017}




\section{International Journal of Science and Research (IJSR) \\ ISSN (Online): 2319-7064}

Index Copernicus Value (2015): 78.96 | Impact Factor (2015): 6.391

Table 1. Indicators of research instruments

\begin{tabular}{|l|l|}
\hline \multicolumn{1}{|c|}{ Variables } & \multicolumn{1}{|c|}{ Indicator } \\
\hline Teacher Performance & 1. Student Achievement \\
& 2. Level of Knowledge \\
& 3. Ability \\
& 4. Social Behavior \\
\hline Teacher's attitude & 1. Cognitive \\
& 2. Affective \\
& 3. Conative \\
\hline Quality Supervision & 1. Curriculum \\
& 2. Manpower \\
& 3. Administration \\
& 4. Facilities and infrastructure \\
& 5. Public relations \\
\hline
\end{tabular}

The study population is a public high school teacher who located in DKI Jakarta. The number of questionnaires distributed and received by respondents was 215 questionnaires then returned only about 175 questionnaires. The minimum number of samples for a survey study recommended 100 samples [30], [31].

Table 2: General Characteristics of Respondents

\begin{tabular}{|c|c|c|c|}
\hline \multicolumn{2}{|c|}{ Category } & Frequency & Percentage \\
\hline \multirow{2}{*}{ Gender } & Man & 66 & $37.71 \%$ \\
\cline { 2 - 4 } & Women & 109 & $62.29 \%$ \\
\hline \multirow{3}{*}{ Age } & $21-30$ & 25 & $14.29 \%$ \\
\cline { 2 - 4 } & $31-40$ & 98 & $56.00 \%$ \\
\cline { 2 - 4 } & $41-50$ & 52 & $29.71 \%$ \\
\hline \multirow{3}{*}{ Education } & Bachelor degree & 123 & $70.29 \%$ \\
\cline { 2 - 4 } & Master & 49 & $28.00 \%$ \\
\cline { 2 - 4 } & Doctor & 3 & $1.71 \%$ \\
\hline
\end{tabular}

Table 2 shows the characteristics of the study respondents divided into categories of sex, age, and education. For the gender category obtained, the majority of respondents are women with a percentage of $62.29 \%$ or 109 respondents. Age category got the majority of respondents aged between 31 40 years with a rate of $56.00 \%$ or 98 respondents. And the education category of majority respondents has still educated strata one with the percentage of $70.29 \%$ or 123 respondents. Multiple linear regression analyzed data with the help of IBM SPSS program. Teacher performance variable $(\mathrm{Y})$ as the dependent variable, during teacher attitude $\left(\mathrm{X}_{1}\right)$ and quality of supervision $\left(\mathrm{X}_{2}\right)$ as the independent variable. Measurement of validity and reliability using Alpha Cronbach.

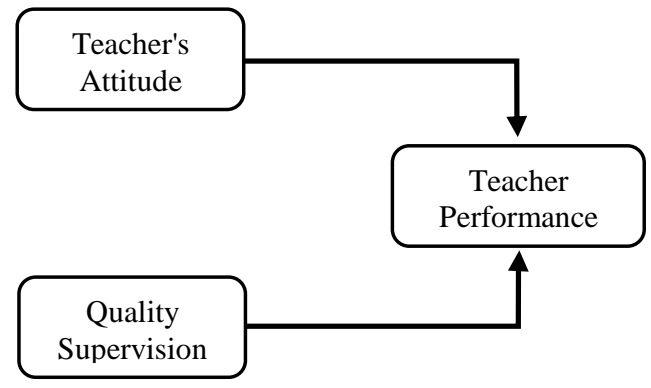

Figure 1: Model of Research Structure

From the model obtained two hypothesis that is:

$\mathrm{H}_{1}$ : There is a significant influence on teachers' attitude variable and teacher performance

$\mathrm{H}_{2}$ : There is a significant influence on the quality of supervision variables and teacher performance.

\section{Result and Discussion}

\subsection{Multiple Linear Regression Analysis Test}

The coefficient of determination $\left(\mathrm{R}^{2}\right)$ essentially measures the extent of the ability to explain the variation of the dependent variable. The ratio of determination is between zero and one. To know the magnitude of the independent variable in influencing the dependent variable can understand through the coefficient of determination is indicated by the value of adjusted $\mathrm{R}$ square $\left(\mathrm{R}^{2}\right)$ [32].

Table 3: Coefficient of Determination

\begin{tabular}{|c|c|c|c|}
\hline$R$ & $R$ Square & Adjusted $R$ Square & Std. Error of the Estimate \\
\hline $.920^{\mathrm{a}}$ & .773 & .769 & 1.46340 \\
\hline
\end{tabular}

Relationship attitude and quality of supervision on teacher performance can know from the amount of coefficient of determination (Adjusted $\mathrm{R}$ Square). With the useful contribution of $0.769(76.90 \%)$ and the rest of $23.10 \%$ influenced by other variables not examined in this study.

Analysis of Variance (ANOVA) is used to determine whether the independent variables simultaneously have a significant effect on the dependent variable. The degree of trust used is 0.05 . If the value of sig. Smaller than 0.05 it can state that all independent variables simultaneously have a significant effect on the dependent variable. The output in table 5 as follows:

Table 4: Analysis of Variance (ANOVA)

\begin{tabular}{|c|c|c|c|c|c|}
\hline & Sum of Squares & $d f$ & Mean Square & $F$ & Sig. \\
\hline Regression & 758.763 & 2 & 379.381 & 177.153 & $.000^{\mathrm{b}}$ \\
\hline Residual & 368.346 & 172 & 2.142 & & \\
\hline Total & 1127.109 & 174 & & & \\
\hline
\end{tabular}

Table 4 shows that the sig value obtained is 0.000 or small from the probability value 0.05 . From these results proves that simultaneously there is a significant influence on attitudes and quality of supervision on teacher performance.

Regression testing is used to determine whether the independent variables are partially significant or not to the dependent variable. The degree of significance used is 0.05 . If the considerable value is less than the degree of trust, then we accept the alternative hypothesis, which states that an independent variable significantly affects the dependent variable [32]. The output is as follows:

Table 5: Regression Coefficients

\begin{tabular}{|c|c|c|c|}
\hline & Coefficients & $t$ & Sig. \\
\hline (Constant) & 6.892 & 4.648 & .000 \\
\hline Teacher Attitude $\left(\mathrm{X}_{1}\right)$ & .550 & 13.544 & .000 \\
\hline Quality Supervision $\left(\mathrm{X}_{2}\right)$ & .243 & 5.300 & .000 \\
\hline
\end{tabular}

The model of multiple regression equations from the calculation result can formulate as follows:

$$
Y=6.892+0.550 X_{1}+0.243 X_{2}
$$

The results of the analysis can interpret as follows:

- The value of the coefficient of variable X1 is positive that is equal to 0,550 . It indicates an increase in attitude variable $(\mathrm{X} 1)$ of $1 \%$ will increase teacher performance

\section{Volume 6 Issue 11, November 2017}




\section{International Journal of Science and Research (IJSR) \\ ISSN (Online): 2319-7064}

Index Copernicus Value (2015): 78.96 | Impact Factor (2015): 6.391

(Y) by $0,550 \%$ assuming other variables are considered fixed.

- The coefficient value of variable X2 is the positive value of 0.243 . It indicates that the improvement of supervisor quality variable $(\mathrm{X} 2)$ by $1 \%$ will increase teacher's performance (Y) by $0,243 \%$ assuming another variable is considered fixed.

\subsection{Hypothesis Testing between attitude variable to Teacher Performance $\left(\mathrm{H}_{1}\right)$}

Basic decision:

- If the value of sig. $<0.05$ means there is a significant influence between attitude variable on teacher performance.

- If the value of sig. $>0.05$ means there is no significant influence between attitude variable on teacher performance.

Table 5 shows that the sig value obtained by attitude variable of 0.000 or less than 0.05 it can conclude that there is a significant influence between attitude variable on teacher performance. To improve teacher performance is obtained from teacher professional attitude. This result shows that junior high school teachers in DKI Jakarta already have knowledge and confidence in their work, have a picture of career enhancement as teachers, have high competence, new initiatives to achieve better job, desire to improve diagnostic skills and make successful, submissive and obedient to the legislation, actively involved in the organization, relationships between teachers put forward the principle of kinship, carry out professional duties with high sense of responsibility, obedient to the principal related to the policies issued for the purpose of schooling, and carry out teaching and learning activities in accordance with the demands of the development of science and technology.

According to [33], attitude is a personal picture of a person who is born through a physical movement and a mind's response to a state or an object, while defining one's attitude on an object is a feeling or emotion, and a second factor is a response or a tendency to react. As a reaction, beliefs always associated with two alternatives, namely likes or dislikes, according to and executes or avoids things.

In general, a teacher's professional attitude seen from external factors. However, it does not reflect how well the teacher's potential as an educator.

A professional is a work or activity undertaken by a person and a source of livelihood that requires skills, skills, and skills that meet specific standards of quality or norm and requires professional education [34]. Teachers as professional educators are always expected to be an example for the community around him.

Teacher profession is one of the objects of psychology associated with positive and negative feelings. The teacher's response, whether positive or negative, to his job, will determine his business. It can say that teachers who have positive feelings about their trade would have excellent and responsible attributes. According to [35], the factors influencing professional attitudes of the teacher should receive proper attention, such as (a) socioeconomic circumstances, (b) workplace situations, (c) relationships among co-workers, leadership, and principal evaluations, d) the teacher's moral, and physical and spiritual health.

\subsection{Hypothesis Testing between supervision quality variable on Teacher Performance $\left(\mathrm{H}_{2}\right)$}

Basic decision:

- If the value of sig. $<0.05$ means there is a significant influence on the quality of supervision variables on teacher performance.

- If the value of sig. $>0.05$ means there is no significant influence on the quality of supervision variables on teacher performance.

Table 5 shows that the sig value obtained by the quality of supervision variable is 0.000 or smaller than 0.05 it can conclude that there is a significant influence on the quality of supervision variable on teacher performance. The principal is the most critical person in a school because it is the key to developers and improvement of an education. Indicators of the success of the school if the school is functioning well, especially if student achievement can reach the maximum. According to [28], supervision is the business effort of school staff in leading teachers and other staff in improving teaching including stimulating, selecting teacher growth and development and revising educational goals, instructional materials, methods and teaching evaluations.

The education process will run effectively and efficiently if the teacher has adequate competence. But if we understand again about the content contained in each type of skill, as has been widely submitted by educational experts to become a competent teacher is not something that is easy. In addition to being influenced by capability, teacher performance is also affected by the principal's leadership.

The concept of modern supervision is formulated by [26], i.e., guidance is an aid in the development of better learning situations. This formulation implies that the supervision service covers the entire teaching and learning situation (goal, material, technique, method, teacher, student, an environment). Learning situation is what should be improved and improved through supervising activities. Thus, the supervision services cover all aspects of education and teaching.

The role of the principal in improving the competence of teachers which in turn will enhance the performance of teachers is needed [36]. Including teachers regularly in training programs, empowering teachers, encouraging and referrals is the responsibility of principals in developing teacher competence. Likewise, with the provision of facilities that support the improvement of teacher performance becomes the responsibility of the principal. To realize and improve teachers' competence requires a genuine effort from the teachers themselves, principals, supervisors and the government. The result of the research shows that there is a positive influence from the influence of the principal's

\section{Volume 6 Issue 11, November 2017}




\section{International Journal of Science and Research (IJSR) \\ ISSN (Online): 2319-7064}

Index Copernicus Value (2015): 78.96 | Impact Factor (2015): 6.391

supervision so that the better the principal's supervision will increase the teacher's performance.

\section{Conclusions}

Quality of education is one of the benchmarks that determine the dignity or progress of a nation. By looking at the quality of education of a society/country, one will be able to estimate the rank of the country among the countries in the world. Teachers are one component of education that plays a vital role in educational success; teachers are expected to play the role of an ideal teacher. One way to improve the quality of education is to develop teacher performance. Teacher performance is teacher perception on teacher work performance related to work quality, responsibility, honesty, cooperation, and initiative.

The teacher is a learned profession where he is required to do his best to run his job as best he can. As a professional then the task of teachers as educators, teachers, and coaches should be able to impact on their students. In this case, the teacher should be able to improve its performance which is the capital for the success of education.

\section{References}

[1] M. G. Moore and G. Kearsley, Distance education: A systems view of online learning. Cengage Learning, 2011.

[2] L. Darling-Hammond, "Teacher quality and student achievement," Educ. Policy Anal. Arch., vol. 8, p. 1, 2000.

[3] J. G. Nicholls, The competitive ethos and democratic education. Harvard University Press, 1989.

[4] W. L. Sanders, S. P. Wright, and S. P. Horn, "Teacher and classroom context effects on student achievement: Implications for teacher evaluation," J. Pers. Eval. Educ., vol. 11, no. 1, pp. 57-67, 1997.

[5] Ballou, Dale. and Podgursky, Michael John., Teacher pay and teacher quality. WE Upjohn Institute, 1997.

[6] I. Ajzen, Attitudes, Personality, and Behavior, 2nd ed. Berkshire, England: Open University Press, 2005.

[7] R. G. Tharp and R. Gallimore, Rousing minds to life: Teaching, learning, and schooling in social context. Cambridge University Press, 1991.

[8] C. Manathunga and J. Goozée, "Challenging the dual assumption of the 'always/already'autonomous student and effective supervisor," Teach. High. Educ., vol. 12, no. 3, pp. 309-322, 2007.

[9] Chance, Paul., Learning and behavior. Nelson Education, 2013.

[10] Lucio, William H. and McNeil, John D., Supervision in thought and action. McGraw-Hill Companies, 1979.

[11]S. P. Robbins, Organizational Behavior. Pearson Education India, 2009.

[12] Schwartz, Barry., Psychology of learning and behavior. WW Norton \& Co, 1989.

[13] Certo, Samuel C. and Certo, S Trevis., Modern management: Concepts and skills. Pearson Higher Ed, 2013.

[14] Glasman, Naftaly S., Evaluation-based leadership:
School administration in contemporary perspective. SUNY Press, 1986.

[15] Twigg, Carol A., "The need for a national learning infrastructure," Educom Rev., vol. 29, p. 16, 1994.

[16]Rue, Leslie., L. Byars, and Ibrahim, Nabil., Management: Skills \& Application. McGraw-Hill Higher Education, 2012.

[17]Hoy, Wayne K. and Miskel, Cecil G., Theory research and practice, vol. 278. Educational administration, New York: Random House, 1987.

[18] Baltus, Rita K., Personal Psychology for Life and Work, 5th ed. New York: McGraw-Hill Book Company, 1998.

[19] Robinson, Nancy M., King, Richard A., and Morgan, Clifford T., Introduction to psychology. McGraw-Hill, 1979.

[20] Darley, John M., Glucksberg, Sam., and Kinchla, Ronald A., Psychology, 5th ed. New Jersey: Prentice Hall, 1991.

[21]Baron, Robert A. and Greenberg, Jerald., Behavior in Organizations: Understanding and Managing the Human Side of Work: Color Transparencies. Prentice Hall, 1997.

[22] J. Cohen, Statistical power analysis for the behavioral sciences, 2nd ed. Hillsdale, New Jersey: Lawrence Erlbaum Associates, 1988.

[23] Downs, Anthony. and Corporation, Rand., Inside bureaucracy. Little, Brown Boston, 1967.

[24] Wiles, Jon. and Bondi, Joseph., Supervision: A guide to practice. Prentice Hall, 2004.

[25] Sallis, Edward., Total quality management in education. Routledge, 2014.

[26] Wiles, Kimball. and Lovell, John T., "Supervision for better schools," 1975.

[27] Bonstingl, John Jay., Schools of Quality: An Introduction to Total Quality Management in Education. ERIC, 1992.

[28] Koralek, Derry G., L. J. Colker, and Dodge, Diane Trister., The what, why, and how of high-quality early childhood education: A guide for on-site supervision. ERIC, 1995.

[29] B. H. Kam, "Style and quality in research supervision: the supervisor dependency factor," High. Educ., vol. 34, no. 1, pp. 81-103, 1997.

[30]M. Q. Patton, Qualitative Research and Evaluation Methods, 3rd ed. Thousand Oaks, California: SAGE Publications, Inc., 2002.

[31] J. R. Fraenkel and N. E. Wallen, How to Design and Evaluate Research in Education, 7th ed. New York: McGraw-Hill Higher Education, 2009.

[32] Perry R. Hinton, I. Mcmurray, and C. Brownlow, SPSS Explained, 2nd ed. New York: Routledge, 2014.

[33] Walgito, Bimo., "Pengantar Psikologi Umum." Andi, 2004.

[34] Pemerintah Republik Indonesia, Undang-Undang No. 14 Tahun 2005 tentang Guru dan Dosen. 2005.

[35] Departemen Pendidikan Nasional, "Penelitian Tindakan Kelas." Direktorat Jenderal Pendidikan Dasar dan Menengah, Jakarta, 2003.

[36] Marks, Helen M. and S. M. Printy, "Principal leadership and school performance: An integration of transformational and instructional leadership," Educ. Adm. Q., vol. 39, no. 3, pp. 370-397, 2003. 